Jurnal Ilmu Ilmu Agribisnis: Journal of Agribusiness Science, 9(2), Mei 2021

\title{
PREFERENSI KONSUMEN TERHADAP BUAH-BUAHAN DI KOTA BANDAR LAMPUNG
}

\author{
(The Consumer Preferences for Fruits in Bandar Lampung City)
}

Riski Tuan Abda'u, Bustanul Arifin, Muhammad Ibnu

Jurusan Agribisnis, Fakultas Pertanian, Universitas Lampung, J1. Prof. Dr. Soemantri Brojonegoro No. 1
Bandar Lampung 35145, e-mail : bustanul.arifin@fp.unila.ac.id

\begin{abstract}
Fruit consumption in Indonesia, especially in Lampung Province, has not reached the Nutrient Adequacy Ratio (NAR) yet, and this threatens the health of young people in the future. Efforts to improve the consumption begin by analyzing the influence of social and personal factors then evaluate consumer preferences for fruits in Bandar Lampung. The consumer preferences explained by different attributes combination for several fruits, such as mangoes, oranges, and bananas. Data were collected with the survey method to 100 respondents. Social factors significantly influence fruit consumption. The social factors relate to the influence of other peoples that affects fruits consumptions. Price is an essential attribute considered by consumers when choosing fruits. Consumers prefer cheap fruits, sweet tasted, small, and clean skinned.
\end{abstract}

Key words: conjoint analysis, consumption, fruit, preferences.

\section{PENDAHULUAN}

Buah-buahan memiliki kandungan vitamin, mineral, dan serat yang berfungsi sebagai antioksidan atau penangkal senyawa jahat dalam tubuh. Konsumsi buah yang cukup merupakan salah satu indikator sederhana gizi seimbang, karena dapat menjaga tekanan darah, kadar gula, dan kolesterol darah serta dapat mencegah gangguan pencernaan dan risiko obesitas (Kementerian Kesehatan Republik Indonesia 2018).

Konsumsi buah di Indonesia hanya sebesar 67 gram/kapita/hari dari 150 gram/kapita/hari yang dianjurkan oleh Badan Kesehatan Dunia atau WHO. Provinsi Lampung memiliki tren konsumsi buah yang juga tidak mencapai Angka Kecukupan Gizi (BPS 2016).

Provinsi Lampung memiliki jumlah penduduk yang besar, yaitu 8.289.577 jiwa (BPS 2017). Rendahnya konsumsi buah pada jumlah masyarakat yang besar dapat menyebabkan gangguan kesehatan dan penurunan kualitas sumberdaya manusia secara masif. Kota Bandar Lampung berperan penting dalam konsumsi buah di Provinsi Lampung, karena memiliki kepadatan penduduk terbesar.

Konsumsi buah merupakan salah satu bentuk pengambilan keputusan jika dilihat dari sudut pandang perilaku konsumen. Faktor sosial dan faktor pribadi berperan penting dalam perilaku konsumen secara umum (Kotler 2002). Faktor sosial dan pribadi belum dipastikan berpengaruh terhadap konsumsi buah di Kota Bandar Lampung. Andarwangi, Indriani dan Prasmatiwi (2016) pernah meneliti tentang gaya hidup rumah tangga dalam mengonsumsi buah di Kota Bandar Lampung. Penelitian tersebut belum membahas pengaruh faktor sosial dan faktor pribadi terhadap konsumsi buah.

Konsumsi buah juga ditentukan oleh preferensi yang menjelaskan tentang tingkat kesukaan konsumen terhadap atribut buah. Atribut buah merupakan ciri khas yang melekat pada buah. Atribut produk dapat membentuk profil buah. Profil buah dapat mempengaruhi konsumen dalam memilih buah-buahan.

Buah mangga, jeruk, dan pisang banyak tersedia di Kota Bandar Lampung, namun belum ada penelitian tentang preferensi konsumen terhadap ketiga buah tersebut. Peneliti terdahulu yang mempelajari perilaku konsumen buah belum membahas preferensi secara spesifik. Preferensi konsumen adalah kecenderungan konsumen dalam memilih produk sesuai tingkat kesukaan setiap konsumen.

Preferensi konsumen terhadap buah-buahan dipengaruhi oleh kombinasi atribut dan level yang dihadapkan. Hasil penelitian preferensi konsumen dapat menambah literatur baru tentang buah- 
buahan. Penelitian tentang preferensi konsumen terhadap buah mangga, jeruk dan pisang di Kota Bandar Lampung penting untuk dilakukan. Berdasarkan latar belakang dan rumusan masalah yang telah dipaparkan, tujuan penelitian ini adalah menganalisis pengaruh faktor sosial dan faktor pribadi konsumen terhadap konsumsi buah mangga, jeruk dan pisang di Kota Bandar Lampung serta menganalisis preferensi konsumen terhadap buah mangga, jeruk dan pisang di Kota Bandar Lampung.

\section{METODE PENELITIAN}

Metode pengumpulan data yang digunakan adalah metode survei. Metode survei merupakan pendekatan metode deskriptif untuk memperoleh data dari sejumlah sampel tertentu. Data diperoleh dengan penyusunan daftar pertanyaan pada kuesioner dan wawancara secara langsung. Teknik pengumpulan data konsumsi dilakukan dengan cara recall. Konsumen diminta untuk mengingat kembali jumlah buah yang dihabiskan dalam sepekan atau sebulan. Teknik pengumpulan data preferensi dilakukan dengan evaluasi kombinasi atribut dan tingkatan pada setiap buah.

Penelitian dilakukan di Pasar Way Halim, Pasar Tempel Way Kandis, Pasar Tugu, Pasar Pasir Gintung, Mall Boemi Kedaton, Trans Mart Lampung, Pasar Swalayan Chandra Superstore Tanjung Karang dan Pasar Swalayan Giant Kedaton. Pemilihan lokasi didasarkan pada hasil prasurvei. Letak pasar yang strategis dan ketersediaan buah yang beragam adalah alasan pemilihan pasar-pasar tersebut. Pengambilan data dilakukan pada bulan April hingga Mei tahun 2019.

Data yang digunakan terdiri dari data primer dan sekunder. Data primer berupa karakteristik pribadi dan sosial konsumen serta evaluasi konsumen terhadap atribut buah. Data sekunder terdiri dari data kecamatan, pasar swalayan dan pasar tradisional di Kota Bandar Lampung. Teknik pengambilan sampel yang dipilih adalah non probability sampling, yaitu dengan judgement sampling.

Menurut Nazir (2005), judgement sampling dilakukan dengan kriteria-kriteria yang telah dirumuskan sebelumnya oleh peneliti. Pemilihan teknik tersebut dikarenakan tidak seluruh individu dapat menjadi sampel penelitian. Kriteria responden adalah berusia 19-64 tahun; mengonsumsi buah minimal satu kali dalam
Tabel 1. Penentuan atribut buah berdasarkan tingkat kepentingan

\begin{tabular}{lcc}
\hline \multicolumn{1}{c}{ Atribut Buah } & $\begin{array}{c}\text { Rerata Skor } \\
\text { Kepentingan }\end{array}$ & Ranking \\
\hline Rasa & 3,70 & 1 \\
Harga & 3,50 & 2 \\
Warna kulit & 3,35 & 3 \\
Ukuran & 3,10 & 4 \\
Aroma & 2,95 & 5 \\
Kandungan vitamin & 2,85 & 6 \\
Varietas & 2,60 & 7 \\
\hline
\end{tabular}

sepekan terakhir; berperan sebagai pengambil keputusan. Jumlah sampel yang digunakan sebanyak 100 orang responden. Menurut Green dan Srinivasan (1978), jumlah sampel minimum yang disarankan pada penelitian yang menggunakan analisis konjoin adalah 100 orang.

\section{Pengaruh Faktor Sosial dan Faktor Pribadi Terhadap Konsumsi Buah Dianalisis dengan Regresi Linear Berganda}

Analisis regresi linear berganda digunakan untuk menjawab tujuan pertama, yaitu pengaruh faktor sosial dan pribadi konsumen terhadap konsumsi buah mangga, jeruk dan pisang di Kota Bandar Lampung. Model persamaan yang digunakan adalah sebagai berikut:

$Y_{i}=\beta_{0}+\beta_{1} X_{1}+\beta_{2} X_{2}+\beta_{3} X_{3}+\beta_{4} X_{4}+\beta_{5} X_{5}+\beta_{6}$ $D_{1}+\beta_{7} D_{2}+e$

Keterangan:

$\mathrm{Y}_{\mathrm{i}}=$ Konsumsi buah (1:mangga, 2:jeruk, 3:pisang) (gram/hari)

$\beta_{0}=$ Konstanta

$\beta_{\mathrm{i}}=$ Koefisien

$\mathrm{X}_{1}=$ Usia

$\mathrm{X}_{2}=$ Pendapatan $(\mathrm{Rp} / \mathrm{bulan})$

$\mathrm{X}_{3}=$ Jumlah anggota rumah tangga

$\mathrm{X}_{4}=$ Jarak pembelian $(\mathrm{km})$

$\mathrm{X}_{5}=$ Lama pendidikan (tahun)

$\mathrm{D}_{1}=$ Jenis kelamin (1:perempuan, 0:lainnya)

$\mathrm{D}_{2}=$ Pengaruh orang lain (1:dipengaruhi, 0 : lainnya)

\section{Preferensi Konsumen Terhadap Atribut Buah Mangga, Jeruk dan Pisang ditentukan dengan Analisis Konjoin}

Analisis konjoin digunakan untuk menjawab tujuan kedua, yaitu preferensi konsumen terhadap buah mangga, jeruk dan pisang di Kota Bandar Lampung. Langkah-langkah yang dilakukan sebagai berikut: 
Tabel 2. Penentuan atribut dan level atribut buah mangga, jeruk dan pisang

\begin{tabular}{lllll}
\hline \multicolumn{1}{c}{ Atribut } & \multicolumn{1}{c}{ Level Atribut } & \multicolumn{1}{c}{ Buah Mangga } & Buah Jeruk & Buah Pisang \\
\hline Harga (H) & Murah (H1) & $11.000-15.000$ & $11.000-15.000$ & $13.000-15.000$ \\
& Cukup Murah (H2) & $16.000-20.000$ & $16.000-20.000$ & $16.000-18.000$ \\
Rasa (R) & Mahal (H3) & $21.000-25.000$ & $32.000-41.000$ & $19.000-21.000$ \\
& Canis (R1) & Manis & Manis & Manis \\
Ukuran (U) & Kecil (U1) & Cukup Manis & Cukup Manis & Cukup Manis \\
& Sedang (U2) & 3 Buah/Kg & 11 Buah/Kg & 10 Buah/Kg \\
& Besar (U3) & 2 Buah/Kg & 9 Buah/Kg & 8 Buah/Kg \\
Warna Kulit & Tanpa Bercak & Tanpa Bekas Getah & Tanpa Bercak & Tuah $/ \mathrm{Kg}$ \\
(WK) & (WK1) & & Hitaming \\
& Ada Bercak (WK2) & Ada Berkas Getah & Ada Bercak Hitam & Hijau Kekuningan \\
\hline
\end{tabular}

1) Beberapa atribut dipilih berdasarkan tingkat kepentingan menurut responden. Pada penelitian ini dipilih empat atribut dengan skor kepentingan tertinggi. Rincian tingkat kepentingan atribut tertera pada Tabel 1 .

Atribut rasa dianggap paling penting bagi calon konsumen, dengan rata-rata sebesar 3,73. Atribut harga merupakan atribut penting kedua, kemudian warna kulit dan ukuran. Atribut buah yang terpilih selanjutnya ditambahkan level atau tingkatan. Pemaparan atribut dan level tertera pada Tabel 2. Atribut harga dan ukuran memiliki 3 tingkatan, rasa dan warna kulit memiliki 2 tingkatan.

2) Prosedur orthogonal dilakukan untuk mendapatkan kombinasi tertentu. Kombinasi yang seharusnya dihasilkan adalah sebanyak 36 kombinasi $(3 \times 2 \times 3 \times 2)$. Kombinasi yang terlalu banyak dapat mempersulit konsumen dalam penilaian. Prosedur orthogonal SPSS digunakan agar tidak semua kombinasi harus dianalisis. Hasil orthogonal menunjukkan terpilih 9 kombinasi yang harus dinilai oleh konsumen.

Tabel 3. Hasil prosedur orthogonal SPSS

\begin{tabular}{|c|c|c|c|c|}
\hline \multicolumn{4}{|c|}{ Atribut } & \multirow[b]{2}{*}{$\begin{array}{l}\text { Kombi- } \\
\text { nasi }\end{array}$} \\
\hline $\begin{array}{l}\text { Harga } \\
(\mathrm{H})\end{array}$ & $\begin{array}{l}\text { Rasa } \\
(\mathrm{R})\end{array}$ & $\begin{array}{l}\text { Uku- } \\
\operatorname{ran}(\mathrm{U})\end{array}$ & $\begin{array}{l}\text { Warna } \\
\text { Kulit (WK) }\end{array}$ & \\
\hline H3 & R1 & U1 & WK 2 & 1 \\
\hline H1 & $\mathrm{R} 2$ & U3 & WK 2 & 2 \\
\hline H3 & R1 & U3 & WK 1 & 3 \\
\hline $\mathrm{H} 2$ & $\mathrm{R} 1$ & $\mathrm{U} 2$ & WK 2 & 4 \\
\hline $\mathrm{H} 2$ & $\mathrm{R} 1$ & U3 & WK 1 & 5 \\
\hline H1 & $\mathrm{R} 1$ & U1 & WK 1 & 6 \\
\hline H1 & $\mathrm{R} 1$ & $\mathrm{U} 2$ & WK 1 & 7 \\
\hline $\mathrm{H} 2$ & R2 & U1 & WK 1 & 8 \\
\hline $\mathrm{H} 3$ & $\mathrm{R} 2$ & $\mathrm{U} 2$ & WK 1 & 9 \\
\hline
\end{tabular}

3) Konsumen memberikan skor dari kombinasi yang disukai (9) hingga kombinasi yang paling tidak disukai (1). Pendapat konsumen digunakan untuk penentuan preferensi dengan analisis konjoin. Model yang digunakan pada analisis konjoin dapat dirumuskan sebagai berikut:

$\mu(x)=a_{0}+a_{1 j} X_{1 j}+a_{2 j} X_{2 j}+a_{3 j} X_{3 j}+a_{4 j} X_{4 j} \ldots$

Keterangan:

$\mu(\mathrm{x})=$ Utilitas dari setiap stimuli buah $\mathrm{x}$

$\mathrm{a}_{0}=$ Konstanta atau total utilitas seluruh atribut

$\mathrm{a}_{\mathrm{ij}}=$ Utilitas atribut (i) pada level (j)

$\mathrm{X}_{\mathrm{ij}}=$ Bernilai 1 jika atribut (i) dan level (j) terjadi, 0 lainnya

4) Estimasi utilitas pada setiap stimuli $\mu(x)$ pada ketiga buah dilakukan. Jika $\mu(\mathrm{x})$ bernilai positif atau lebih besar, maka konsumen menyukai atribut tersebut. SPSS subfile summary juga menunjukkan urutan kepentingan atribut.

5) Keakurasian peramalan diukur dengan koefisien korelasi, yaitu nilai Pearson's R dan Kendall's Tau. Nilai tersebut diuji dengan $\alpha=0,05$. Jika berbeda nyata, maka pendapat konsumen dapat diterima dan dianalisis.

\section{HASIL DAN PEMBAHASAN}

\section{Karakteristik Konsumen}

Konsumen termuda pada penelitian ini berusia 19 tahun, sedangkan konsumen tertua adalah 53 tahun. Sebanyak 91 persen konsumen berada pada masa remaja akhir, masa dewasa awal dan dewasa akhir. Konsumen pada masa dewasa awal (26-35 tahun) berjumlah paling banyak, yaitu 35 persen. Konsumen laki-laki berjumlah 25 persen, sedangkan konsumen perempuan berjumlah 75 persen. 
Tabel 4. Konsumsi buah mangga, jeruk dan pisang per rumah tangga dan per kapita per hari di Kota Bandar Lampung

\begin{tabular}{lcr}
\hline Buah & $\begin{array}{c}\text { Rerata konsumsi } \\
\text { (g/RT/hari) }\end{array}$ & $\begin{array}{c}\text { Rerata konsumsi } \\
\text { (g/kapita/hari) }\end{array}$ \\
\hline Mangga & 162,671 & 62,308 \\
Jeruk & 138,029 & 55,467 \\
Pisang & 140,357 & 55,238 \\
\hline
\end{tabular}

Konsumen dengan pendidikan terakhir SMA berjumlah paling banyak, yaitu 52 persen. Pendapatan terendah responden adalah Rp1.000.000,00 per bulan. Pendapatan tertinggi konsumen sebesar Rp9.500.000,00 per bulan. Pendapatan rata-rata konsumen sebesar Rp3.251.000,00 per bulan.

Jumlah anggota rumahtangga berkisar antara 1 sampai 6 orang. Terdapat 26 persen konsumen memiliki jumlah tanggungan keluarga sebanyak 4 orang. Jarak terdekat kediaman konsumen dari pasar sejauh 0,20 kilometer, sedangkan jarak terjauh adalah 5 kilometer. Sebanyak 62 persen responden dipengaruhi oleh orang lain dalam mngonsumsi buah-buahan.

Konsumsi buah mangga lebih banyak daripada buah jeruk dan pisang, yaitu sejumlah 62,308 gram per kapita per hari (Tabel 4). Jika konsumen hanya mengonsumsi salah satu buah, maka konsumsi buah di Kota Bandar Lampung belum mencukupi AKG yang dianjurkan (150 gram per kapita per hari). Apabila ketiga buah dikonsumsi secara bersamaan, maka dapat memenuhi AKG. Kelemahan penelitian ini adalah pengumpulan data konsumsi dengan teknik recall tidak dilakukan secara tepat dan rinci. Konsumsi buah sepekan seharusnya dirincikan dengan konsumsi per hari.
Ketidaktepatan recall membuat konsumen memperkirakan jumlah konsumsi buah yang kurang akurat. Data konsumsi buah mangga, jeruk dan pisang tidak dibedakan berdasarkan jenis (varietas) buah dan asal buah (lokal/impor). Data konsumsi buah yang diperoleh masih sangat umum. Kelemahan tersebut dapat dikembangkan peneliti lain untuk mendapatkan data konsumsi buah-buahan dengan lebih baik dan tepat.

\section{Pengaruh Faktor Sosial dan Faktor Pribadi Terhadap Konsumsi Buah Dijawab dengan Hasil Analisis Regresi Linear Berganda}

\section{Uji Normalitas dan Uji Multikolinearitas}

Uji normalitas dan multikolinearitas dilakukan untuk mengetahui kelayakan pengambilan keputusan. Pengujian dengan KolmogorovSmirnov Test pada residual regresi konsumsi buah mangga, jeruk dan pisang menunjukkan bahwa nilai signifikansi lebih besar dari 0,05.

Hasil pengujian tersebut menunjukkan bahwa data observasi terdistribusi normal. Pada hasil uji kolinearitas (Tabel 5), semua variabel bebas memiliki nilai VIF $<10$ dan nilai toleransi $>0,05$. Tidak terdapat hubungan yang erat antara variabel bebas. Dengan demikian, hasil analisis dapat diterjemahkan untuk mengambil keputusan.

\section{Hasil Uji F}

Nilai F-hitung buah mangga, jeruk dan pisang lebih besar dari F-tabel $(2,111)$ dengan signifikansi lebih kecil dari 0,05 (Tabel 5). Hal tersebut berarti bahwa faktor pribadi dan faktor sosial secara bersamaan mempengaruhi konsumsi buah mangga, jeruk dan pisang.

Tabel 5. Analisis pengaruh faktor sosial dan pribadi terhadap konsumsi buah mangga, jeruk dan pisang di Kota Bandar Lampung

\begin{tabular}{|c|c|c|c|c|c|c|c|}
\hline \multirow{2}{*}{ Variabel } & \multicolumn{2}{|c|}{ Konsumsi Mangga } & \multicolumn{2}{|c|}{ Konsumsi Jeruk } & \multicolumn{2}{|c|}{ Konsumsi Pisang } & \multirow{2}{*}{ VIF } \\
\hline & Koefisien & Sig. & Koefisien & Sig. & Koefisien & Sig. & \\
\hline $\operatorname{Usia}\left(\mathrm{X}_{1}\right)$ & $-0,156$ & 0,219 & $-0,198$ & 0,128 & $-0,029$ & 0,817 & 1,782 \\
\hline Pendapatan $\left(\mathrm{X}_{2}\right)$ & $-0,248$ & 0,183 & $-0,152$ & 0,301 & $-0,080$ & 0,558 & 2,169 \\
\hline $\mathrm{Jml}$ anggota $\mathrm{RT}\left(\mathrm{X}_{3}\right)$ & $0,246^{*}$ & 0,078 & $0,238^{*}$ & 0,094 & $0,283 * *$ & 0,039 & 2,121 \\
\hline Jarak pembelian $\left(\mathrm{X}_{4}\right)$ & $-0,096$ & 0,383 & $-0,254 * *$ & 0,022 & $-0,205 * *$ & 0,047 & 1,211 \\
\hline Jenis kelamin $\left(\mathrm{D}_{1}\right)$ & $0,296 * *$ & 0,010 & 0,035 & 0,760 & $-0,090$ & 0,395 & 1,291 \\
\hline Pendidikan $\left(\mathrm{X}_{5}\right)$ & 0,024 & 0,851 & $-0,189$ & 0,142 & $-0,162$ & 0,184 & 1,713 \\
\hline Pengaruh orang lain $\left(\mathrm{D}_{2}\right)$ & $0,300 * * *$ & 0,004 & $0,311 * * *$ & 0,003 & $0,303 * * *$ & 0,002 & 1,079 \\
\hline R Square & & 0,210 & & 0,217 & & 0,210 & - \\
\hline F-hitung & 3,198 & g.0,005) & 3,295 (s & $0,004)$ & 3,49 & $(0,002)$ & - \\
\hline
\end{tabular}


Faktor pribadi terdiri dari variabel usia, pendapatan, lama pendidikan dan jenis kelamin. Faktor sosial terdiri dari variabel jumlah anggota rumah tangga, jarak pembelian dan pengaruh orang lain. Nilai $R$ Square yang kecil menunjukkan bahwa pada model penelitian terdapat kekurangan. Ketidakmampuan model menjelaskan populasi disebabkan, karena penggunaan variabel dan sampel yang kurang tepat. Sampel yang digunakan terlalu sedikit untuk menganalisis tujuh variabel bebas, sehingga $R$ Square yang dihasilkan rendah.

\section{Hasil Uji t}

Variabel usia $\left(\mathrm{X}_{1}\right)$ tidak mempengaruhi konsumsi buah mangga, jeruk dan pisang (Tabel 5). Pertambahan usia pada konsumen tidak terbukti dapat menambah jumlah konsumsi buah. Hasil tersebut mematahkan pernyataan Bahria dan Triyati (2010) yang menyebutkan bahwa generasi muda kurang mengonsumsi buah. Konsumen berusia muda tidak selalu mengonsumsi buah lebih sedikit dari konsumen yang lebih tua.

Pendapatan $\left(\mathrm{X}_{2}\right)$ tidak berpengaruh terhadap konsumsi buah mangga, jeruk dan pisang. Perbedaan jumlah pendapatan konsumen tidak mempengaruhi jumlah buah yang dikonsumsi. Hasil ini bertolak belakang dengan penelitian Rachman, Mustika dan Kusumawati (2017). Rachman et al. (2017) mengklaim bahwa pendapatan berhubungan signifikan dengan perilaku konsumsi buah. Penelitian tersebut menggunakan sampel yang lebih spesifik, yaitu remaja di sekolah. Perbedaan hasil wajar terjadi karena asal pendapatan yang tidak sama, sehingga tidak menunjukkan pengaruh yang nyata.

Menurut Andarwangi et al. (2016), permintaan pisang dipengaruhi oleh pendapatan. Permintaan diukur dengan pengeluaran yang menunjukkan kemampuan pembelian konsumen. Konsumsi diukur dengan jumlah barang yang dihabiskan. Kemampuan pembelian tidak menentukan kemauan untuk menghabiskan buah-buahan yang telah dibeli.

Jumlah anggota rumah tangga $\left(\mathrm{X}_{3}\right)$ berpengaruh terhadap konsumsi buah mangga, jeruk dan pisang dengan tingkat kepercayaan 90 persen dan 95 persen. Pertambahan anggota rumah tangga dapat meningkatkan kuantitas konsumsi buah. Perilaku konsumsi salah satu anggota keluarga dapat mempengaruhi anggota keluarga lainnya. Hasil tersebut sejalan dengan penelitian Desfaryani, Hartoyo dan Anggraeni (2016).
Desfaryani et al. (2016) menyatakan bahwa variabel jumlah anggota rumah tangga berpengaruh terhadap permintaan buah. Pengaruh anggota rumah tangga bukan hanya berpengaruh pada permintaan, tetapi juga perilaku konsumsi. Konsumsi buah masyarakat Kota Bandar Lampung dapat berubah sesuai dengan jumlah anggota rumah tangganya.

Jarak pembelian $\left(\mathrm{X}_{4}\right)$ berpengaruh negatif terhadap konsumsi buah jeruk dan pisang. Pertambahan jarak pembelian dapat menurunkan jumlah konsumsi jeruk dan pisang. Hal ini dikarenakan buah tersebut hanya tersedia di pasar-pasar yang cukup jauh dari kediaman konsumen. Hasil ini sesuai dengan hasil penelitian Ralibi, Ichdayati dan Rochaeni (2015). Ralibi et al. (2015) menyatakan bahwa tempat pembelian mempengaruhi konsumsi buah. Tempat pembelian yang jauh dari kediaman konsumen dapat mengurangi konsumsi buah tersebut atau bahkan menggantikannya dengan produk lain.

Jenjang pendidikan $\left(\mathrm{X}_{5}\right)$ tidak menunjukkan pengaruh pada konsumsi buah mangga, jeruk dan pisang. Tingginya pendidikan yang telah ditempuh konsumen tidak dapat meningkatkan konsumsi buah. Artinya, konsumen yang berpengetahuan luas belum tentu mengonsumsi buah lebih banyak.

Variabel pengaruh orang lain $\left(\mathrm{D}_{1}\right)$ mempengaruhi konsumsi buah mangga, jeruk dan pisang dengan tingkat kepercayaan 99 persen. Konsumen yang mengonsumsi buah karena pengaruh orang lain terbukti lebih banyak mengonsumsi buah. Pengaruh orang lain dapat mengubah perilaku konsumsi buah. Pengaruh orang lain dapat berasal dari keluarga, teman sekolah, teman kerja, tokoh publik dan iklan.

Variabel jenis kelamin $\left(D_{2}\right)$ mempengaruhi komsumsi buah mangga dengan tingkat kepercayaan 95 persen. Konsumen perempuan dapat mengonsumsi buah mangga lebih banyak daripada konsumen laki-laki.

Faktor pribadi dan sosial berpengaruh terhadap perilaku konsumen secara umum (Kotler 2002). Hasil penelitian sesuai dengan teori dasar, namun terdapat perbedaan proporsi pengaruh faktor pribadi dan sosial terhadap konsumsi buah. Konsumsi buah mangga, jeruk dan pisang lebih banyak dipengaruhi oleh faktor sosial dibandingkan faktor pribadi. Faktor sosial yang berpengaruh meliputi variabel pengaruh orang lain, jumlah tanggungan keluarga dan jarak pembelian. 
Besarnya pengaruh faktor sosial karena manusia adalah makhluk sosial yang dapat dipengaruhi oleh lingkungan. Peran lingkungan melalui hubungan sosial yang terjalin antar individu dapat mengubah perilaku sehari-hari, termasuk konsumsi buah.

Pengaruh faktor sosial harus menjadi landasan utama untuk meningkatkan konsumsi buah di Kota Bandar Lampung. Kota Bandar Lampung dengan masyarakat perkotaan yang heterogen dan berpikir yang terbuka, seharusnya lebih mudah menyerap informasi baru.

\section{Preferensi Konsumen Terhadap Atribut Buah Mangga, Jeruk dan Pisang Ditentukan dengan Hasil Analisis Konjoin}

Preferensi konsumen diinterpretasikan dari hasil analisis konjoin melalui nilai estimasi utilitas. Level atribut dengan nilai utilitas paling tinggi mempengaruhi preferensi konsumen. Nilai utilitas yang betanda positif berarti lebih disukai konsumen. Hasil analisis konjoin pada atribut buah mangga tertera pada Tabel 6 .

Harga buah mangga yang berharga Rp11.000,00Rp15.000,00 memiliki nilai utilitas tertinggi, yaitu sebesar 1,362. Artinya harga mangga yang murah mempengaruhi preferensi konsumen. Harga Rp16.000,00-Rp20.000,00 lebih disukai konsumen dibandingkan harga Rp21.000,00-Rp25.000,00.

Buah mangga dengan rasa manis lebih diharapkan daripada yang terasa cukup manis. Ukuran mangga kecil (berjumlah 4 buah per kilogram) paling disukai konsumen. Mangga yang berjumlah 3 buah per kilogram lebih disukai daripada berjumlah 2 buah per kilogram. Buah mangga dengan kulit tanpa bekas getah lebih disukai daripada yang ada bekas getah.
Seluruh sub-atribut yang bernilai positif digabungkan dalam satu kombinasi. Kombinasi tersebut adalah gambaran profil buah yang menjadi preferensi konsumen.

Preferensi konsumen terhadap buah mangga berharga Rp11.000,00-Rp15.000,00 rasanya manis, berukuran 4 buah per kilogram dan kulit tanpa bekas getah. Buah jeruk yang menjadi pilihan utama konumen berharga Rp11.000,00Rp15.000,00 rasanya manis, berukuran 11 buah per kilogram, dan kulit tanpa bercak hitam. Buah pisang yang paling disukai konsumen berharga Rp13.000,00-Rp15.000,00 rasanya manis, berukuran 10 buah per kilogram, dan kulit berwarna kuning.

Secara umum, atribut harga buah yang paling murah, jumlah banyak per kilogram, rasa manis, dan kulit bersih mempengaruhi preferensi konsumen. Konsumen cenderung memilih atribut pada level yang tinggi.

Konsumen menginginkan buah yang semurah mungkin, tetapi dengan kualitas sebaik mungkin. Buah dengan seluruh atribut yang paling baik sulit didapatkan, maka preferensi dapat dianalisis lebih rinci dengan tingkat kepentingan atribut.

Tingkat kepentingan atribut adalah pertimbangan konsumen dalam memilih buah. Atribut dengan nilai tertinggi berarti paling penting bagi konsumen. Tingkat kepentingan atribut buah mangga, jeruk dan pisang terdapat pada Tabel 7 .

Harga merupakan atribut yang paling penting bagi konsumen dalam memilih buah. Tingkat kepentingan harga buah mangga, jeruk dan pisang bernilai masing-masing sebesar 43,499; 47,441; dan 44,768 .

Tabel 6. Hasil analisis konjoin dalam menentukan preferensi konsumen terhadap buah mangga, jeruk dan pisang di Kota Bandar Lampung

\begin{tabular}{llcrr}
\hline \multirow{2}{*}{ Atribut } & \multicolumn{1}{c}{ Level Atribut } & \multicolumn{3}{c}{ Utilitas } \\
\cline { 3 - 5 } & Murah (H1) & Buah Mangga & Buah Jeruk & Buah Pisang \\
\hline Harga (H) & Cukup Murah (H2) & 1,362 & 1,356 & 1,417 \\
& Mahal (H3) & 0,346 & 0,689 & 0,450 \\
\multirow{4}{*}{ Rasa (R) } & Manis (R1) & $-1,708$ & $-2,044$ & $-1,867$ \\
& Cukup Manis (R2) & 0,756 & 0,723 & 0,808 \\
Ukuran (U) & Kecil (U1) & $-0,756$ & $-0,723$ & $-0,808$ \\
& Sedang (U2) & 0,219 & 0,169 & 0,200 \\
\multirow{4}{*}{ Warna Kulit (WK) } & 0,029 & $-0,074$ & $-0,130$ \\
& Besar (U3) & $-0,248$ & $-0,094$ & $-0,070$ \\
& Tanpa Bercak (WK1) & 0,138 & 0,293 & 0,168 \\
& Ada Bercak (WK2) & $-0,138$ & $-0,293$ & $-0,168$ \\
\hline
\end{tabular}


Tabel 7. Tingkat kepentingan atribut buah mangga, jeruk dan pisang di Kota Bandar Lampung

\begin{tabular}{lrrr}
\hline $\begin{array}{c}\text { Tingkat } \\
\text { Kepentingan }\end{array}$ & Mangga & Jeruk & Pisang \\
\hline Harga & 43,499 & 47,441 & 44,768 \\
Rasa & 21,363 & 20,410 & 22,398 \\
Ukuran & 23,391 & 20,272 & 19,513 \\
Warna Kulit & 11,747 & 11,877 & 13,321 \\
\hline
\end{tabular}

Konsumen sangat mementingkan harga dibandingkan atribut lainnya. Konsumen lebih memilih buah yang murah, meskipun tidak dengan rasa, ukuran dan kulit yang terbaik. Konsumen memahami bahwa harga buah berbanding lurus dengan kualitas yang didapatkan. Hal ini berkaitan dengan penelitian yang dilakukan oleh Octaviani, Indriani dan Situmorang (2014). Octaviani et al. (2014) menjelaskan bahwa harga berperan dalam pembelian kembali produk jus buah. Hal tersebut menunjukkan bahwa kepentingan harga berlaku untuk produk buah segar dan olahannya.

Atribut ukuran terpenting kedua pada buah mangga, yaitu sebesar 23,391. Buah mangga yang terlalu besar kurang disukai konsumen. Ukuran buah dapat menentukan jumlah buah yang diperoleh. Kuantitas buah yang lebih banyak membuat konsumen berpendapat bahwa buah tersebut lebih murah. Mayoritas konsumen memilih buah bukan hanya untuk diri sendiri, tetapi untuk seluruh anggota keluarga.

Atribut rasa pada buah jeruk dan pisang, dinilai konsumen sebagai atribut terpenting kedua. Rasa buah jeruk dan pisang yang manis lebih disukai konsumen. Hal tersebut sesuai dengan penelitian Rajagukguk, Sayekti dan Situmorang (2013) yang mengemukakan bahwa atribut rasa sangat penting bagi konsumen dalam memilih buah jeruk. Atribut yang paling tidak penting bagi konsumen adalah warna kulit. Konsumen menilai bahwa kebersihan kulit bukanlah ciri buah dengan rasa yang manis.

Kepercayaan terhadap hasil analisis konjoin dapat dinilai melalui koefisien korelasi. Koefisien korelasi didefiniskan dengan nilai Pearson's R dan Kendall's Tau pada Tabel 8.

Tabel 8. Koefisien korelasi analisis konjoin atributbuah mangga, jeruk, dan pisang

\begin{tabular}{lccc}
\hline \multicolumn{1}{c}{ Nilai } & Mangga & Jeruk & Pisang \\
\hline Pearson's R & 0,985 & 0,989 & 0,987 \\
Kendal's Tau & 0,986 & 0,889 & 0,944 \\
\hline
\end{tabular}

Nilai Pearson's R pada buah mangga, jeruk dan pisang masing-masing sebesar 0,$985 ; 0,989$; dan 0,987 (Tabel 8). Nilai Kendall's Tau pada ketiga buah masing-masing sebesar 0,986; 0,889; dan 0,944 . Kedua nilai tersebut memiliki signifikansi sebesar 0,000 pada seluruh buah yang ditelliti. Artinya, data observasi tidak jauh berbeda dengan estimasi. Hasil analisis konjoin untuk preferensi konsumen terhadap buah mangga, jeruk dan pisang dapat dipercaya.

\section{KESIMPULAN DAN SARAN}

Faktor sosial terbukti berperan besar pada jumlah konsumsi buah mangga, jeruk dan pisang. Hal ini terjadi karena pada dasarnya manusia adalah makhluk sosial yang dapat dipengaruhi oleh lingkungan. Perilaku mengonsumsi buah secara terus menerus dan berulang dapat ditiru oleh manusia lainnya. Informasi tentang pentingnya mengonsumsi buah lebih mudah diserap oleh konsumen dengan penjelasan dan pembuktian secara langsung.

Atribut harga, rasa, ukuran dan warna kulit pada tingkatan lebih tinggi terbukti mempengaruhi preferensi konsumen. Harga adalah atribut terpenting yang dipertimbangkan konsumen dalam mengonsumsi buah mangga, jeruk dan pisang. Konsumen lebih memilih buah yang murah meskipun tidak dengan atribut rasa, ukuran dan warna kulit yang paling baik. Konsumen menyukai buah yang berukuran lebih kecil. Konsumen mempertimbangkan jumlah anggota keluarga dalam memilih buah. Kuantitas buah yang lebih banyak lebih disukai oleh konsumen di Kota Bandar Lampung.

Peneliti lain dalam memperoleh data konsumsi buah-buahan perlu menggunakan metode recall yang tepat dan rinci. Penggunaan metode recall yang tepat dapat menyajikan data konsumsi yang lebih rinci dan akurat. Peneliti dan konsumen tidak harus menerka jumlah konsumsi buah yang dihabiskan dalam waktu tertentu. Data konsumsi buah berdasarkan varietas dapat dikumpulkan untuk perbandingan buah dengan varietas yang berbeda-beda. Varietas buah perlu digunakan sebagai atribut dalam menganalisis preferensi konsumen. Pengembangan tersebut dapat menambah kajian baru tentang evaluasi konsumen terhadap atribut buah. Peneliti yang menganalisis pengaruh aspek pribadi dan sosial terhadap konsumsi buah harus memilih variabel dan sampel yang tepat, sehingga dapat mewakili populasi. 
Konsumsi buah dapat ditingkatkan dengan penyediaan buah dengan harga yang terjangkau. Harga buah yang murah dapat diwujudkan dengan membentuk platform online berbentuk aplikasi penjualan buah. Penjualan buah secara online dapat mempermudah konsumen dalam memperoleh buah-buahan, sehingga tidak harus mempertimbangkan jarak pembelian. Harga yang terjangkau, kualitas buah yang baik dan pemberian hadiah (reward) dapat meningkatkan minat konsumen untuk mengonsumsi buah. Pemberian hadiah dapat dilakukan kepada konsumen yang setiap hari mengonsumsi buah dengan jumlah dan jenis tertentu. Ketertarikan konsumen akan hadiah yang ditawarkan dapat memicu peningkatan konsumsi buah secara masif. Pengaruh sosial yang diberikan antar konsumen dapat mengubah paradigma masyarakat, yaitu mengonsumsi buah sebagai tren masa kini.

\section{DAFTAR PUSTAKA}

Andarwangi T, Indriani Y, dan Prasmatiwi FE. 2016. Gaya hidup rumah tangga dalam mengonsumsi buah-buahan di Bandar Lampung. Jurnal Ilmu Ilmu Agribisnis, 4 (1): 94-103. http://jurnal.fp. unila.ac.id/index.php/JIA/article/view/1219. [20 Februari 2019].

BPS [Badan Pusat Statistik]. 2016. Survei Sosial Ekonomi Nasional (SUSENAS). www.bps.go. id. [27 Januari 2019].

2017. Jumlah dan Kepadatan Penduduk Provinsi Lampung Berdasarkan Kabupaten/Kota. www.bps.go. id. [27 Januari 2019].

Bahria dan Triyati. 2010. Faktor-faktor yang terkait dengan konsumsi buah dan sayur pada remaja di Empat SMA Jakarta Barat. Jurnal Kesehatan Masyarakat, 4 (2): 63-71. http://jurnal.fkm.unand.ac.id/index.php/jkma/ article/view/70. [20 Februari 2019].

Desfaryani R, Hartoyo S, dan Anggraeni L. 2016. Permintaan buah-buahan rumahtangga di Propinsi Lampung. Jurnal Agribisnis Indonesia, 4 (2): 137-148. https://journal.ipb. ac.id/index.php/jagbi/article/view/17128 . [20 Februari 2019].

Green PE dan Srinivasan V. 1978. Conjoint Analysis in consumer research: issues and outlook. The Journal of Consumer Research, 5 (2): 103-123. https://academic.oup.com/jcr/ article/5/2/103/1805825. [7 Maret 2019].

KEMKES RI [Kementerian Kesehatan Republik Indonesia]. 2018. Konsumsi Makanan Penduduk Indonesia. Pusat Data dan Informasi, Kementerian Kesehatan Republik Indonesia. www.kemkes.go.id. [8 Maret 2019].

Kotler P. 2002. Manajemen Pemasaran Edisi Millenium Jilid II. PT. Prehallindo. Jakarta.

Nazir M. 2005. Metode Penelitian. Ghalia Indonesia. Jakarta.

Octaviani MW, Indriani Y, dan Situmorang S. 2014. Pengaruh bauran pemasaran (marketing mix) dan perilaku konsumen terhadap pengambilan keputusan pembelian jus buah segar Bandar Lampung. Jurnal Ilmu Ilmu Agribisnis, 2 (2): 133-141. https://jurnal.fp.unila.ac.id/index.php/JIA/artic le/view/736/677\#. [17 Juli 2020].

Rachman BN, Mustika IG, dan Kusumawati IGAW. 2017. Faktor yang berhubungan dengan perilaku konsumsi buah dan sayur siswa SMP di Denpasar. Jurnal Gizi Indonesia, 6 (1): 9-16. https://ejournal.undip. ac.id/index.php/jgi/article/view/17749/12608. [19 Februari 2019].

Rajagukguk MJ, Sayekti WD, dan Situmorang S. 2013. Sikap dan pengambilan keputusan konsumen dalam membeli buah jeruk lokal dan jeruk impor di Bandar Lampung. Jurnal Ilmu Ilmu Agribisnis, 1 (4): 351-357. https://jurnal.fp.unila.ac.id/ index.php/JIA/article/view/713/655. [17 Juli 2020].

Ralibi U, Ichdayati LI, dan Rochaeni S. 2015. Pengaruh kesadaran, persepsi dan preferensi konsumen terhadap perilaku mengkonsumsi buah lokal di kawasan pemukiman Jakarta Timur. Skripsi. Program Studi Agribisnis, Fakultas Sains dan Teknologi, UIN Syarif Hidayatullah. Jakarta. 